\title{
Downregulation of deoxycytidine kinase in cytarabine-resistant mantle cell lymphoma cells confers cross-resistance to nucleoside analogs gemcitabine, fludarabine and cladribine, but not to other classes of anti-lymphoma agents
}

\author{
Magdalena Klanova ${ }^{1,2}$, Lucie Lorkova', Ondrej Vit', Bokang Maswabi', Jan Molinsky ${ }^{1,2}$, Jana Pospisilova ${ }^{1}$, \\ Petra Vockova ${ }^{1,2}$, Cory Mavis $^{3}$, Lucie Lateckova ${ }^{1,2}$, Vojtech Kulvait ${ }^{1}$, Dana Vejmelkova², Radek Jaksa ${ }^{3}$, \\ Francisco Hernandez ${ }^{4}$, Marek Trneny ${ }^{2}$, Martin Vokurka ${ }^{1}$, Jiri Petrak ${ }^{1,5+}$ and Pavel Klener $\mathrm{Jr}^{1,2^{*}+}$
}

\begin{abstract}
Background: Mantle cell lymphoma (MCL) is an aggressive type of B-cell non-Hodgkin lymphoma associated with poor prognosis. Implementation of high-dose cytarabine (araC) into induction therapy became standard-of-care for all newly diagnosed younger MCL patients. However, many patients relapse even after araC-based regimen. Molecular mechanisms responsible for araC resistance in $\mathrm{MCL}$ are unknown and optimal treatment strategy for relapsed/refractory $M C L$ patients remains elusive.

Methods: Five araC-resistant (R) clones were derived by long-term culture of five MCL cell lines (CTRL) with increasing doses of araC up to 50 microM. Illumina BeadChip and 2-DE proteomic analysis were used to identify gene and protein expression changes associated with araC resistance in $\mathrm{MCL}$. In vitro cytotoxicity assays and experimental therapy of $\mathrm{MCL}$ xenografts in immunodeficient mice were used to analyze their relative responsiveness to a set of clinically used anti-MCL drugs. Primary MCL samples were obtained from patients at diagnosis and after failure of araC-based therapies.

Results: Marked downregulation of deoxycytidine-kinase (DCK) mRNA and protein expression was identified as the single most important molecular event associated with araC-resistance in all tested $\mathrm{MCL}$ cell lines and in 50\% primary MCL samples. All R clones were highly (20-1000x) cross-resistant to all tested nucleoside analogs including gemcitabine, fludarabine and cladribine. In vitro sensitivity of $\mathrm{R}$ clones to other classes of clinically used anti-MCL agents including genotoxic drugs (cisplatin, doxorubicin, bendamustine) and targeted agents (bortezomib, temsirolimus, rituximab) remained unaffected, or was even increased (ibrutinib). Experimental therapy of immunodeficient mice confirmed the anticipated loss of anti-tumor activity (as determined by overall survival) of the nucleoside analogs gemcitabine and fludarabine in mice transplanted with R clone compared to mice transplanted with CTRL cells, while the anti-tumor activity of cisplatin, temsirolimus, bortezomib, bendamustine, cyclophosphamide and rituximab remained comparable between the two cohorts.

(Continued on next page)
\end{abstract}

\footnotetext{
* Correspondence: pavel.klener@gmail.com

${ }^{\dagger}$ Equal contributors

'Institute of Pathological Physiology, Charles University in Prague, First

Faculty of Medicine, Prague, Czech Republic

${ }^{2}$ First Department of Medicine - Department of Hematology, General

University Hospital and Charles University in Prague, Prague, Czech Republic

Full list of author information is available at the end of the article
} 
(Continued from previous page)

Conclusions: Acquired resistance of MCL cells to araC is associated with downregulation of DCK, enzyme of the nucleotide salvage pathway responsible for the first phosphorylation (=activation) of most nucleoside analogs used in anti-cancer therapy. The data suggest that nucleoside analogs should not be used in the therapy of MCL patients, who relapse after failure of araC-based therapies.

Keywords: Mantle cell lymphoma (MCL), Cytarabine, Drug resistance, Nucleotide salvage pathway, Proteomics, Mass spectrometry

\section{Background}

Mantle cell lymphoma (MCL) is an aggressive type of Bcell non-Hodgkin lymphoma (NHL) associated with poor prognosis $[1,2]$. In recent years several studies brought evidence that implementation of high-dose cytarabine ( $\mathrm{araC}$ ) into induction therapy, e.g. by sequential chemotherapy by $\mathrm{R}$ (ituximab)-CHOP and R-DHAP regimens, induced higher response rate and prolonged progression-free survival compared to R-CHOP-only [3-5]. Based on these results, implementation of araC into induction therapy became standard of care for all newly diagnosed younger MCL patients. Despite considerable improvement, however, most high-risk MCL patients relapse even after araCbased first-line regimen. Prognosis of relapsed/refractory (RR) MCL is dismal. Currently, there is no second-line standard-of-care for RR-MCL [6]. Available treatment approaches for RR-MCL include cisplatin, fludarabine, cladribine, gemcitabine, temsirolimus, bortezomib, bendamustine, lenalidomide and ibrutinib-based regimen [7-16].

AraC belongs among the backbone anti-leukemia agents [17]. Both, "standard dose" araC (100-200 mg/m2 continuous i.v. infusion for 7 days), and "high dose" araC (HDAC, 2-3 g/m2, 2-4 i.v. three hour administrations every $12-24$ hours) have been widely used in the therapy of acute myelogenous leukemia (AML), as well as in salvage regimen for relapsed B-NHL $[18,19]$. As mentioned above araC appears particularly effective component of multi-agent aggressive immunochemoterapy regimen used in younger MCL patients.

AraC is a prodrug, which must be 1 . transported into the cell, and 2 . within the cell converted into an active drug by phosphorylation by specific phosphokinases of the nucleotide salvage pathway [20]. During "standard dose" cytarabine administration araC is transported into the cell by means of specific transporters, primarily via hENT1/ SLC29A1 [21]. During high-dose cytarabine administration araC also diffuses across plasma membrane independent of the specific transporters [22]. The rate-limiting enzyme of the nucleotide salvage pathway is deoxycytidine-kinase (DCK), which catalyzes the first phosphorylation of araC into araCMP. AraCMP is retained in the cell and undergoes two additional consecutive phosporylations before it can be incorporated into DNA.
The molecular mechanisms of araC resistance in $\mathrm{MCL}$ are unknown. Resistance to araC in myeloid leukemia cells was repeatedly associated with altered expression of genes involved in nucleotide salvage pathway, including downregulation of DCK, or upregulation of key araCinactivating enzymes, namely cytidine-deaminase (CDA) or cytoplasmic 5' nucleotidase (NT5C2) [20-25].

In this study we derived araC-resistant MCL cells, studied their sensitivity to a battery of anti-cancer drugs and elucidated the molecular mechanism responsible for araC resistance in MCL.

\section{Results}

Establishment and characterization of araC-resistant $\mathrm{MCL}$ clones ( $\mathrm{R}$ clones)

Five araC-resistant MCL clones (=R clones) were established by long-term culture of five cytarabine-sensitive MCL cell lines (JEKO-1, MINO, REC-1, HBL-2 and GRANTA-519, =CTRL cell lines) in the presence of increasing doses of araC (up to $50 \mu \mathrm{M}$, comparable with plasma concentration reached in patients treated with high-dose araC) [26]. Resistance of $\mathrm{R}$ clones to araC was confirmed in vitro by proliferation assays (Figure 1). The $\mathrm{R}$ clones tolerated at least 125-1000-fold higher concentrations of araC compared to CTRL cells (Figure 1).

\section{Gene expression profiling of $\mathrm{R}$ clones revealed downregulation of deoxycytidine-kinase (DCK)}

To identify gene and protein expression changes associated with araC resistance in MCL we performed parallel transcriptome profiling and proteomic analysis of $\mathrm{R}$ clones compared to CTRL cell lines. Transcriptomic analysis was performed for each of the $5 \mathrm{MCL}$ cell lines and their respective $\mathrm{R}$ clones in biological duplicates using Illumina BeadChips. The filtered groups of genes with fold change at least \pm 1.5 -fold and adjusted $\mathrm{p}$ value $<0.05$ were annotated and arranged into biologically relevant categories using The Database for Annotation, Visualization and Integrated Discovery (DAVID, Additional file 1: Figure S1). Based on Gene Ontology (GO) terms, the downregulated genes were involved in ribosome structure and function, cell cycle, RNA degradation, antigen processing and presentation, purine metabolism and pyrimidine metabolism 

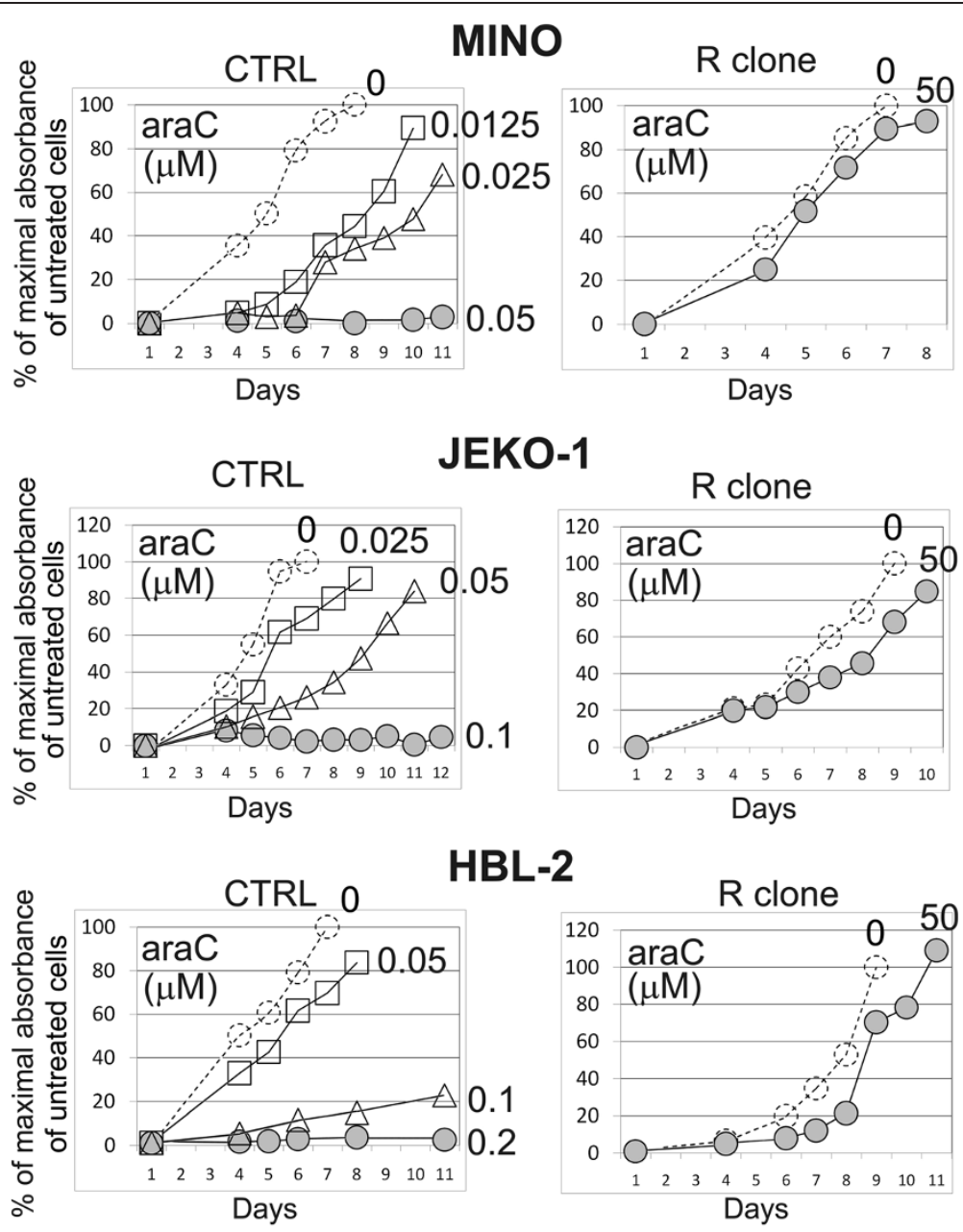

REC-1

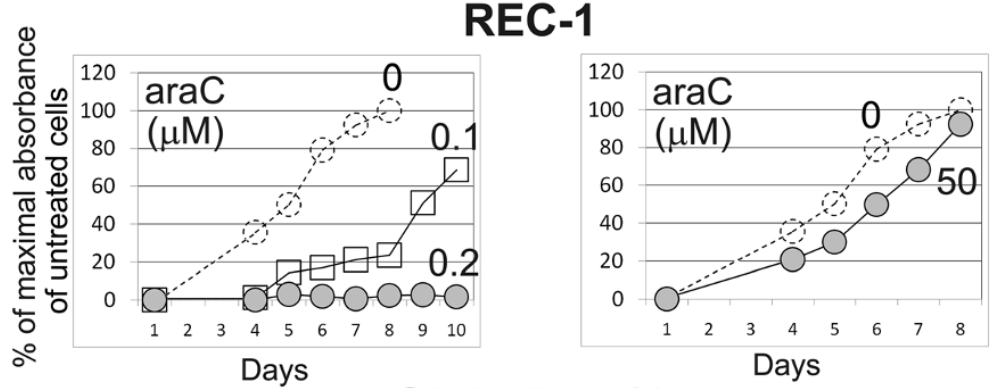

\section{GRANTA-519}
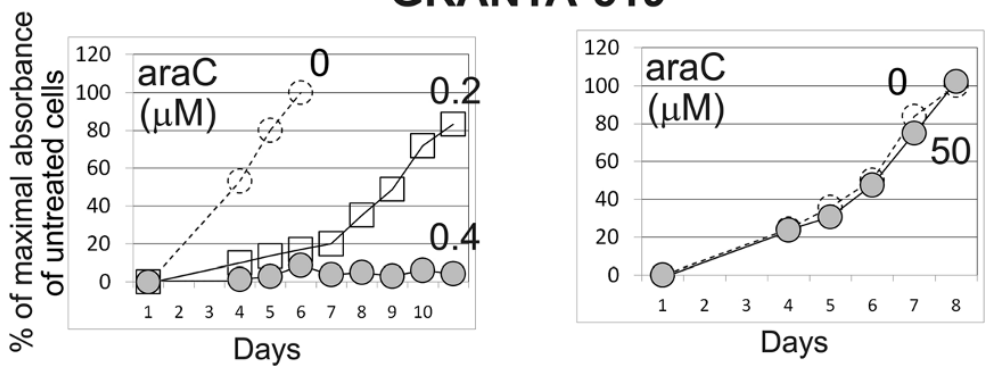

Figure $1 \mathrm{R}$ clones are resistant to $50 \mu \mathrm{M}$ cytarabine. WST-8 cell proliferation assay of $5 \mathrm{MCL}$ cell lines (CTRL) and $5 \mathrm{R}$ clones was carried out as described in Methods. While the lethal dose of cytarabine for CTRL cells ranged from 0.05 to $0.4 \mu \mathrm{M}$, proliferation rate of R clones in $50 \mu \mathrm{M}$ araC was virtually unaffected. Representative example of two independent experiments is shown. Standard deviations were $<5 \%$ for all measurements. 
(Additional file 1: Figure S1A). Among the most upregulated gene groups belonged those involved in graft-vs-host disease, alograft rejection, $B$-cell receptor signaling, cell adhesion molecules, chemokine signaling pathway and Toll-like receptor signaling (Additional file 1: Figure S1B). The only gene consistently differentially expressed across all 5 MCL cell lines was DCK, which was markedly downregulated in all $\mathrm{R}$ clones. Other genes differentially expressed in more than one MCL cell line are shown in Additional file 2: Table S1. Proteomic analysis using 2-DE was applied to Mino R subclone compared to Mino CTRL cell line, and revealed differential expression of several proteins, among them almost 5-fold downregulation of DCK in the Mino $\mathrm{R}$ subclone was the most apparent (Figure 2, Tables 1 and 2). Downregulation of DCK protein (the rate-limiting enzyme of the nucleotide salvage pathway, which catalyzes the first phosphorylation of araC and other nuclosides into their respective monophosphates) was confirmed by western blotting in all five $\mathrm{R}$ clones (Figure 3). DCK expression seemed to be fully abrogated in four R clones (as there was no detectable DCK) and several-fold downregulated in one $\mathrm{R}$ clone compared to the CTRL cells.

\section{AraC-resistant clones are cross-resistant to nucleoside analogs, but remain sensitive to other classes of anti-lymphoma agents}

To identify optimal treatment strategy for araC-resistant MCL we determined sensitivity (or eventual cross-resistance) of all $5 \mathrm{R}$ clones in a battery of cellular toxicity tests. We exposed $\mathrm{R}$ clones and CTRL cells to a panel of clinically used anti-MCL agents in various concentrations and measured their effect on cell proliferation rate. The tested agents included both, classical genotoxic cytostatics and novel targeted drugs. The panel included alkylating agents cisplatin, doxorubicin and bendamustine, nucleoside analogs gemcitabine, cladribine and fludarbine, and targeted drugs bortezomib (proteasome inhibitor), temsirolimus (mTOR inhibitor) and ibrutinib (Bruton tyrosine-kinase (BTK) inhibitor). All five $\mathrm{R}$ clones (resistant to a pyrimidine analog cytarabine) showed cross-resistance not only to another pyrimidine analog gemcitabine (up to 3125fold), but also to purine nucleoside analogs fludarabine and cladribine (approx. 12.5-500-fold, see Figure 4A,B). Sensitivity of the resistant $\mathrm{R}$ clones to other classes of anti-lymphoma agents (i.e. other than nucleoside analogs) remained comparable to the respective CTRL cells (Figure 4C,D), with the exception of ibrutinib. The BTK inhibitor ibrutinib proved to be significantly more cytotoxic to $\mathrm{R}$ clones compared to CTRL cells in vitro (see Figure 4C,D, Additional file 3: Figure S2). R clones also retained in vitro sensitivity to anti-CD20 monoclonal antibody rituximab comparable to CTRL cells as determined by ${ }^{51} \mathrm{Cr}$ release assay, which is standardly used to evaluate

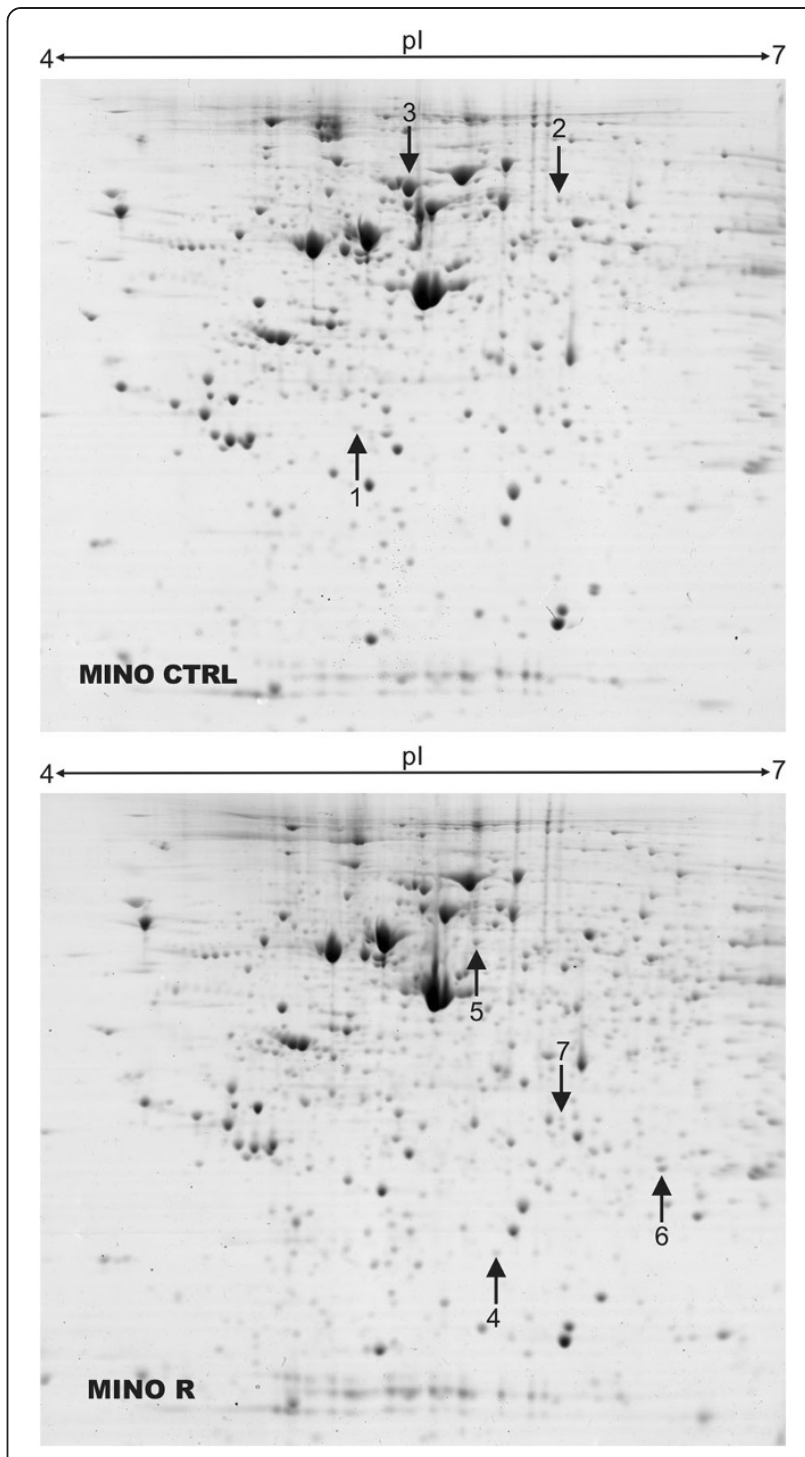

Figure 2 Proteomic analysis of MINO R vs MINO CTRL cells. Two-dimensional electrophoresis of cells MINO R cell versus MINO CTRL cells was performed on $24 \mathrm{~cm}$ gel strips, pH 4.0-7.0, 10\% SDSPAGE. Proteins were stained with Coomassie Brilliant Blue. Differentially expressed proteins are indicated by numbered arrows, spots 13 indicate proteins significantly downregulated in MINO R cells, and spots 4-7 indicate proteins upregulated in MINO R cells.

antibody-dependent cytotoxicity (ADCC) and complementmediated cytotoxicity (CMC) of therapeutic monoclonal antibodies (Figure 5).

\section{Experimental therapy with fludarabine and gemcitabine is ineffective in mice xenografted with araC-resistant clones}

The in vitro tests of cellular toxicity provided important information on direct cellular effects of the tested drugs to the resistant cells. However, in vitro assays do not take into account important systemic pharmacokinetic 
Table 1 List of proteins differentially expressed in MINO R cells identified by 2-DE

\begin{tabular}{|c|c|c|c|c|c|c|}
\hline Spot no. & Accession & Protein name & Fold change & Mascot score & Sequence cov. (\%) & $\mathrm{Mr}$ \\
\hline \multicolumn{7}{|c|}{ Proteins downregulated in MINO R cells } \\
\hline 1 & P27707 & Deoxycytidine kinase & -4.6 & $44^{*}$ & 16 & 30841 \\
\hline 2 & Q99829 & Copine-1 & -4.3 & 102 & 17 & 59649 \\
\hline 3 & P13796 & Plastin-2 & -2 & 453 & 65 & 70814 \\
\hline \multicolumn{7}{|c|}{ Proteins upregulated in MINO R cells } \\
\hline 4 & P07741 & Adenine phosphoribosyltransferase & 5 & 70 & 40 & 19766 \\
\hline 5 & P68363 & Tubulin alpha-1B chain & 5 & 169 & 32 & 50804 \\
\hline 6 & P04792 & Heat shock protein beta-1 & $2 / 3$ & 73 & 32 & 22826 \\
\hline 7 & P31937 & 3-Hydroxyisobutyrate Dehydrogenase, Mitochondrial & $2 / 1$ & $43^{*}$ & 8 & 35712 \\
\hline
\end{tabular}

*Identity of proteins with low Mascot Score was verified by MS/MS (see Table 2).

Included are the proteins with difference in expression at least 2 -fold and statistical significance of the change $p<0.05$. Swiss-Prot no. is the code under which the identified protein is deposited in the Swiss-Prot database. Mascot score helps to estimate the correctness of the individual hit. It is expressed as $-10 \times$ log $(P)$ where $\mathrm{P}$ is the probability that the observed match is a random event. Sequence coverage is the number of amino acids spanned by the assigned peptides divided by the sequence length.

and pharmacodynamic variables, which can have large impact on the drug efficacy in vivo. In addition, some anti-MCL agents cannot be properly tested in vitro, because their mechanism of antitumor activity directly or indirectly depends on the in vivo context, e.g. activation of a prodrug cyclophosphamide in the liver microsome, cooperation of a monoclonal antibody rituximab with complement and cells of the immune system, or antiangiogenic component of temsirolimus activity. Therefore, we used a mouse xenograft model (NOD.Cg-Prkdc ${ }^{\text {scid }}$ $I l 2 g^{t m 1 W j l} / \mathrm{SzJ}$ mice) of MCL to simulate in vivo treatment of araC-sensitive and araC-resistant disease. Intravenous injection of 1 million JEKO-1 MCL cells leads to demise of the xenografted animals due to disseminated lymphoma with median overall survival of approx. 38 days. Experimental therapy of JEKO-1-xenografted immunodeficient mice with single-agent fludarabine and gemcitabine confirmed total loss of anti-tumor activity of purine analog fludarabine and pyrimidine analog gemcitabine (measured as overall survival of experimental animals) in mice transplanted with cytarabine-resistant JEKO-1 R clone compared to mice transplanted with cytarabine-sensitive JEKO-1 CTRL cells (Figure 6). Antitumor activity of cisplatin, temsirolimus, bendamustine, bortezomib, cyclophosphamide and rituximab remained comparable between JEKO-1 R clone and JEKO-1 CTRLxenografted mice in agreement with the in vitro tests (Figure 6).
Analysis of primary MCL samples confirmed that downregulation of DCK is frequently associated with failure of high-dose araC-based treatments

Eight and two primary MCL samples obtained from patients at diagnosis (D1-D8) and at lymphoma relapse after failure of high-dose araC-based treatments (R1-R8) were analyzed by real-time RT-PCR and western blotting, respectively (Table 3, Figure 7A). In four cases downregulation of DCK gene expression was observed in R compared to D samples (difference in $\triangle \mathrm{CT}$ (DCK-GAPDH) between $\mathrm{R}$ and $\mathrm{D}$ samples was $>1$ cycle), while in four cases no change was observed (difference in $\Delta \mathrm{CT}<1$ cycle) (Table 3). Western blotting analysis of the sample R2 compared to D2 revealed marked downregulation of protein DCK thereby confirming the gene expression results (i.e. 4-fold decrease in total DCK mRNA after araC-based therapy). Interestingly, protein DCK in the sample R6 compared to D6 was also moderately downregulated despite its gene expression remained virtually unchanged (Figure 7A, Table 3). In addition to the analysis of MCL samples obtained from the relapsed patients, paired primary cells isolated from two MCL patients (samples D9/R9, and D10/R10) refractory to araC were subject to analysis of gene and protein expression, and determination of their ex vivo sensitivity to nucleoside analogs (Figure 7B,C). The samples were obtained before araC administration (D9, D10), and 14 days after araC administration (R9, R10). Downregulation of both gene

Table 2 Identity of differentially expressed proteins with low mascot score confirmed by MS/MS

\begin{tabular}{|c|c|c|c|c|}
\hline Spot no. & Accession & Protein name & Peptide sequence & Score \\
\hline 1 & P27707 & Deoxycytidine kinase & LKDAEKPVLFFER, QLCEDWEWPEPVAR & 41,46 \\
\hline 7 & P31937 & 3-Hydroxyisobutyrate Dehydrogenase, Mitochondrial & DFSSVFQFLREEETF (C-term), SPILLGSLAHQIYR & 49,28 \\
\hline
\end{tabular}




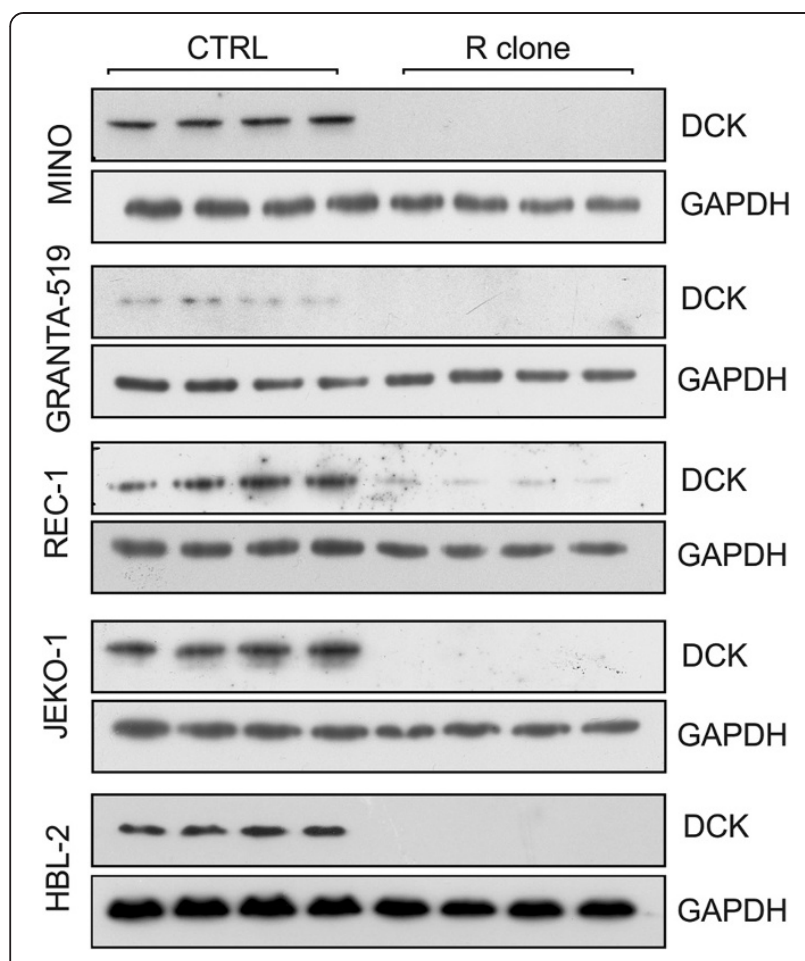

Figure 3 Western blot analysis confirms marked downregulation of protein DCK in all R clones. Relative expression of deoxycytine kinase (DCK) in all five R and CTRL clones. Quadruplicate cell lysates were separated on $12 \%$ SDS-PAGE minigels. Proteins were then transferred onto PVDF membranes, blocked and probed with anti-DCK antibody. Anti-GAPDH antibody was used as the loading control.

and protein DCK expression was confirmed in R9 compared to D9 cells (Figure 7B). Sensitivity of R9 cells to araC, fludarabine and gemcitabine was significantly suppressed compared to D9 cells (Figure 7C). Both gene expression and protein expression of R10 compared to D10 sample remained unchanged (Figure 7B). Interestingly, susceptibility of R10 cells compared to D10 cells to undergo apoptosis after their ex vivo exposure to araC was increased despite the fact that $\mathrm{R} 10$ cells were isolated after administration of four cycles of high-dose araC (Figure 7C).

\section{Discussion}

In this study we analyzed molecular mechanisms of araC resistance in five MCL cell lines and ten paired primary MCL samples obtained before and after araC-based therapies. In addition, we tested optimal treatment strategies for cytarabine-resistant MCL. On molecular level we identified marked and principal downregulation of DCK, the rate-limiting enzyme of nucleotide salvage pathway, in all 5 cytarabine-resistant MCL clones, and in 50\% primary MCL samples obtained from patients, who progressed on or relapsed after araC-based treatments. In $50 \%$ primary MCL samples, no change of DCK expression was observed at time of lymphoma relapse or progression.
Importantly, no upregulation of DCK was observed in any of the analyzed post-treatment samples. Although the analysis of the primary MCL samples indicate that the mechanisms responsible for araC resistance in vivo are more complex than those observed in vitro, it must be emphasized that downregulation of gene and protein DCK was indeed confirmed in a substantial part of the patients' post-treatment samples (Table 3, Figure 7A,B). Interestingly, in one of the two MCL patients primary resistant to araC, no change of DCK expression was observed with slightly increased ex vivo sensitivity of post-treatment MCL cells to araC (Figure 7B,C). This observation could be explained by existence of araCresistant stem cell-like MCL cells that would reside in the niches in lymph nodes (and/or bone marrow) and produce partially araC-sensitive MCL cells mobilized in the peripheral blood. In such a case, elimination of the mobilized MCL cells, but persistence of the stem cell-like MCL compartment, would lead to stable disease, and eventual lymphoma progression (which was the actual course of the disease observed in this patient).

DCK catalyzes the first phosphorylation (=activation necessary for their cytotoxic activity) not only of araC into araCMP, but also of most nucleoside analogs (both pyrimidine and purine-derived) commonly used in anticancer therapy. Using DAVID bioinformatic analyzer purine/pyrimidine metabolism, and B-cell receptor signaling were among the functional cathegories associated with the most downregulated and upregulated genes, respectively. In accordance with these results we subsequently showed that all $\mathrm{R}$ clones were cross-resistant to both pyrimidine analog gemcitabine, and to purine analogs fludarabine and cladribine (all of which are activated by DCK). Sensitivity of $\mathrm{R}$ clones to other types of anti-cancer molecules including genotoxic cytostatics (cisplatin, doxorubicin, bendamustine), targeted drugs (temsirolimus, bortezomib) or biological agents (monoclonal anti-CD20 antibody rituximab) remained unaffected, or was even augmented in the case of BTK inhibitor ibrutinib. The reason, why ibrutinib more effectively eliminated araC-resistant MCL cells remained elusive, but might be at least partially explained by the observed upregulation of $\mathrm{B}$-cell receptor signaling in $\mathrm{R}$ clones compared to CTRL cells (Additional file 1: Figure S1).

The results of our in vitro and in vivo tests combined with the observed decreased expression of DCK in all araC-resistant MCL clones and in 50\% post-treatment primary MCL samples suggest that the resistance of MCL cells to high-dose araC is caused by suppressed araC activation by DCK due to markedly decreased DCK expression. DCK has low substrate preference and phosphorylates both, purines and pyrimidines, including synthetic analogs cytarabine, fludarabine, gemcitabine and cladribine [27-29]. The fact that above-mentioned nucleoside analogs are 


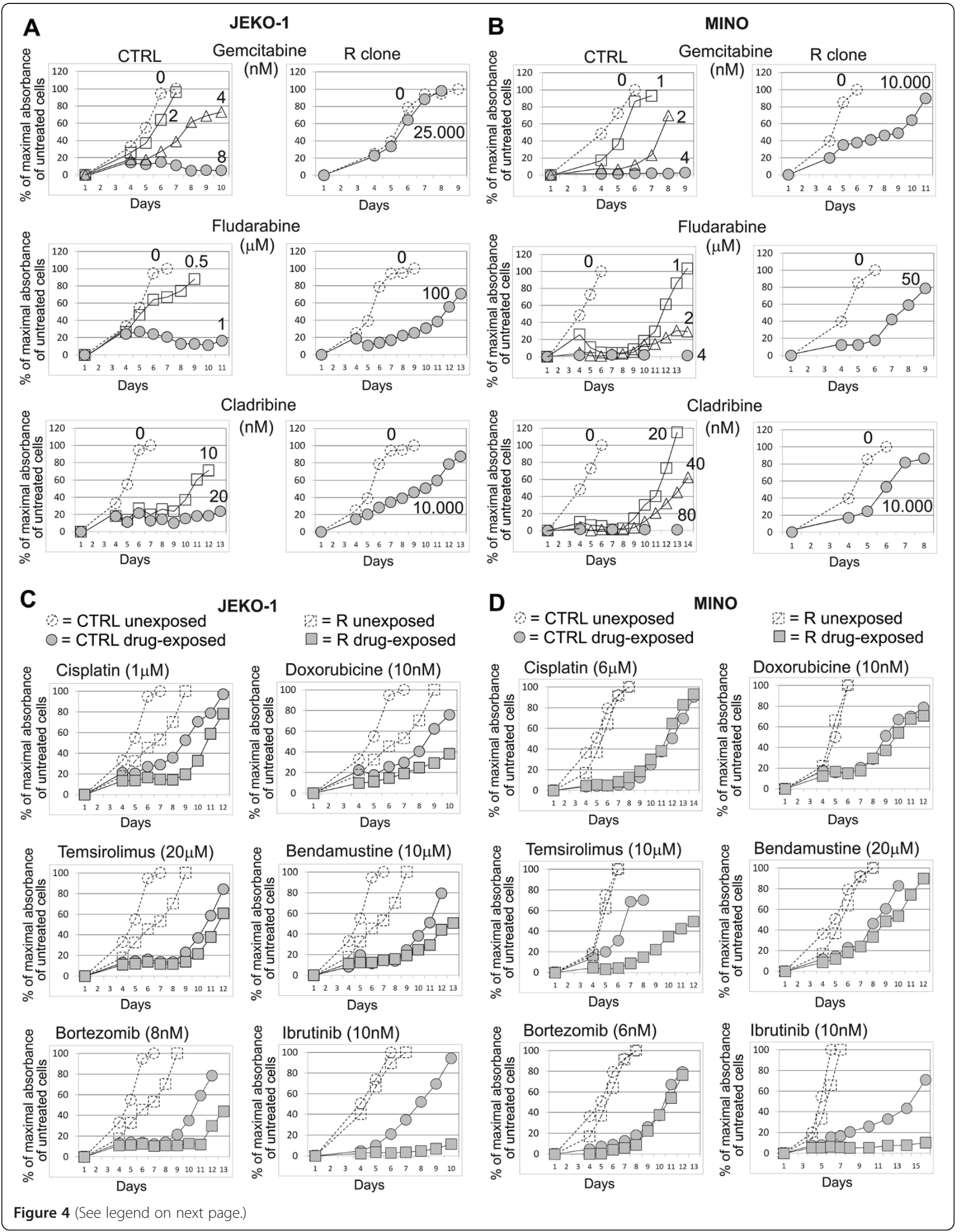


(See figure on previous page.)

Figure $4 \mathrm{R}$ clones are cross-resistant to nucleoside analogs, but remain sensitive to other classes of anti-lymphoma agents. (A-D) WST-8 cell proliferation assays of CTRL cells and R clones were carried out as described in Methods. Maximal absorbance obtained from the untreated cells during the particular experiment $\left(\mathrm{MAX}_{\mathrm{u}}\right)$ was arbitrary set as $100 \%$. Absorbance of medium without cells was used as background (B). For each cell population (both, unexposed and drug-exposed) and for each measurement $\left(M_{1}, M_{2}, M_{3} \ldots M_{X}\right)$ the proliferation curve was calculated as follows:

$\left(M_{x}-B\right) /\left(M A X_{u}-B\right)$. As a consequence, proliferation curves of untreated cells always peak at 100\%, while proliferation curves of drug-exposed cells can terminate below or above $100 \%$. One representative example of two independent experiments carried out both on JEKO-1 (A, C) and MINO (B, D) is shown. Data from the remaining three MCL cell lines (HBL-2, GRANTA-519 and REC-1) are not shown, because they did not significantly differ from those presented for the JEKO-1 and MINO cells. In summary, all $5 \mathrm{R}$ clones were cross-resistant to the tested nucleoside analogs, but remained sensitive to other classes of anti-lymphoma agents with negligible differences between particular MCL cell lines. The only exception to the rule was markedly (>100-fold) increased sensitivity of REC-1 R clone to ibrutinib compared to REC-1 CTRL cells (see Additional file 3: Figure S2). The remaining $4 \mathrm{MCL}$ cell lines (JEKO-1, MINO, GRANTA-519 and HBL-2) showed only approx. 2-fold increased sensitivity to ibrutinib compared to the corresponding CTRL cells. Standard deviations were $<5 \%$ for all measurements presented in Figure 4.

substrates of DCK explains the observed cross-resistance of $\mathrm{R}$ clones to all tested nucleoside analogs, both purineand pyrimidine-derived. Retained sensitivity to other classes of anti-MCL agents (i.e. other than nucleoside analogs) with diverse molecular mechanisms of their respective antitumor activities suggests that no major additional molecular alteration was involved in the development of araC resistance.
Prognosis of patients with relapsed/refractory MCL (RR-MCL) is dismal. Currently there is no standard-ofcare for RR-MCL patients. Second-line treatment approaches include fludarabine, gemcitabine, cladribine, cisplatin, bortezomib, temsirolimus, bendamustine, lenalidomide and ibrutinib-based regimen. We have proved in vitro and in vivo on a mouse xenograft model of $\mathrm{MCL}$ that treatment of patients, who progress on or relapse
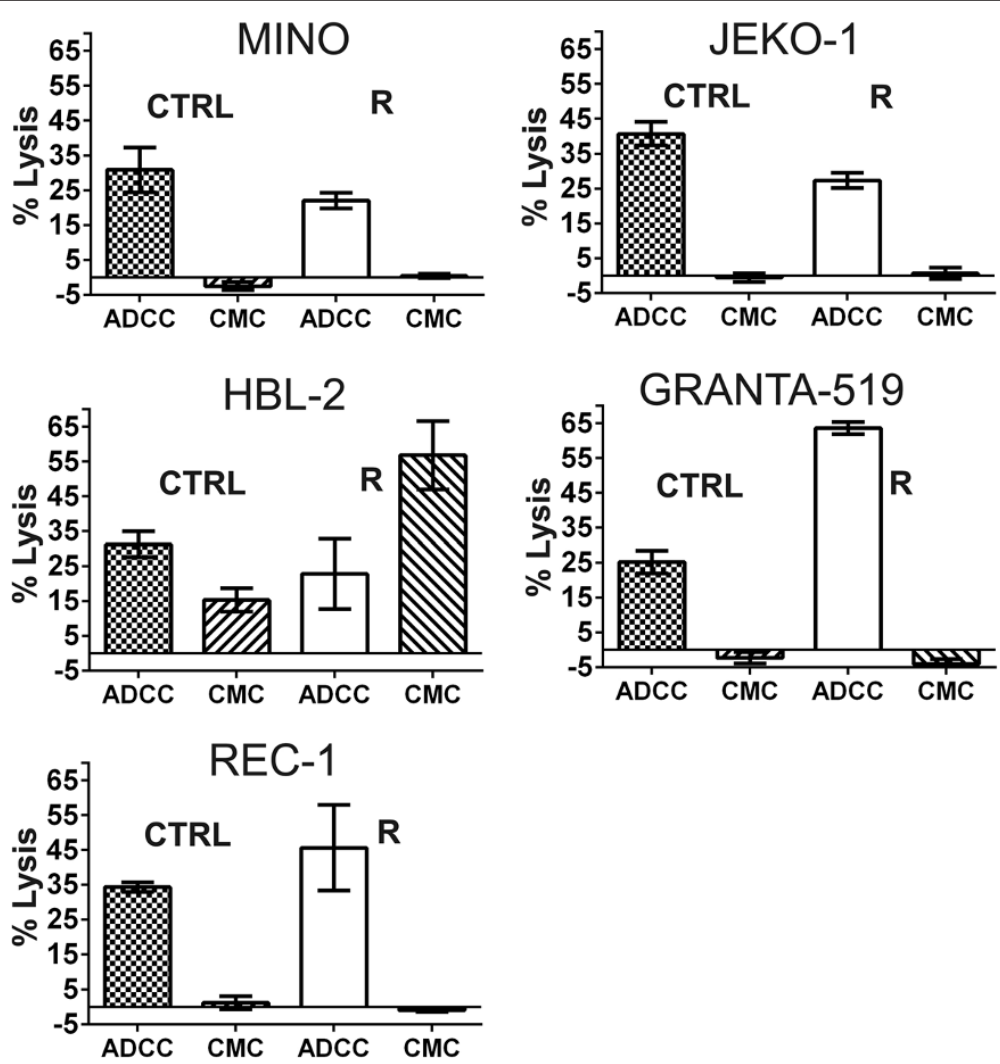

Figure $5 \mathrm{R}$ clones remain sensitive to anti-CD20 monoclonal antibody rituximab. ${ }^{51} \mathrm{Cr}$ release assay was used to assess the impact of the anti-CD20 monoclonal antibody rituximab on complement mediated cytotoxicity (CMC) and antibody dependent cellular cytotoxicity (ADCC). CMC was measurable only in HBL-2 cells (both CTRL and R), but was negligible in the remaining four MCL cell populations (both CTRL and R). In HBL-2 R clone the CMC was significantly increased compared to CTRL. ADCC was measurable in all five MCL cell lines. In JEKO- 1 R clone the ADCC was slightly decreased compared to CTRL. In GRANTA-519 R clone the ADCC was significantly increased compared to CTRL. In MINO, REC-1 and $\mathrm{HBL}-2$ the ADCC remained comparable between $\mathrm{R}$ clone and CTRL cells. 


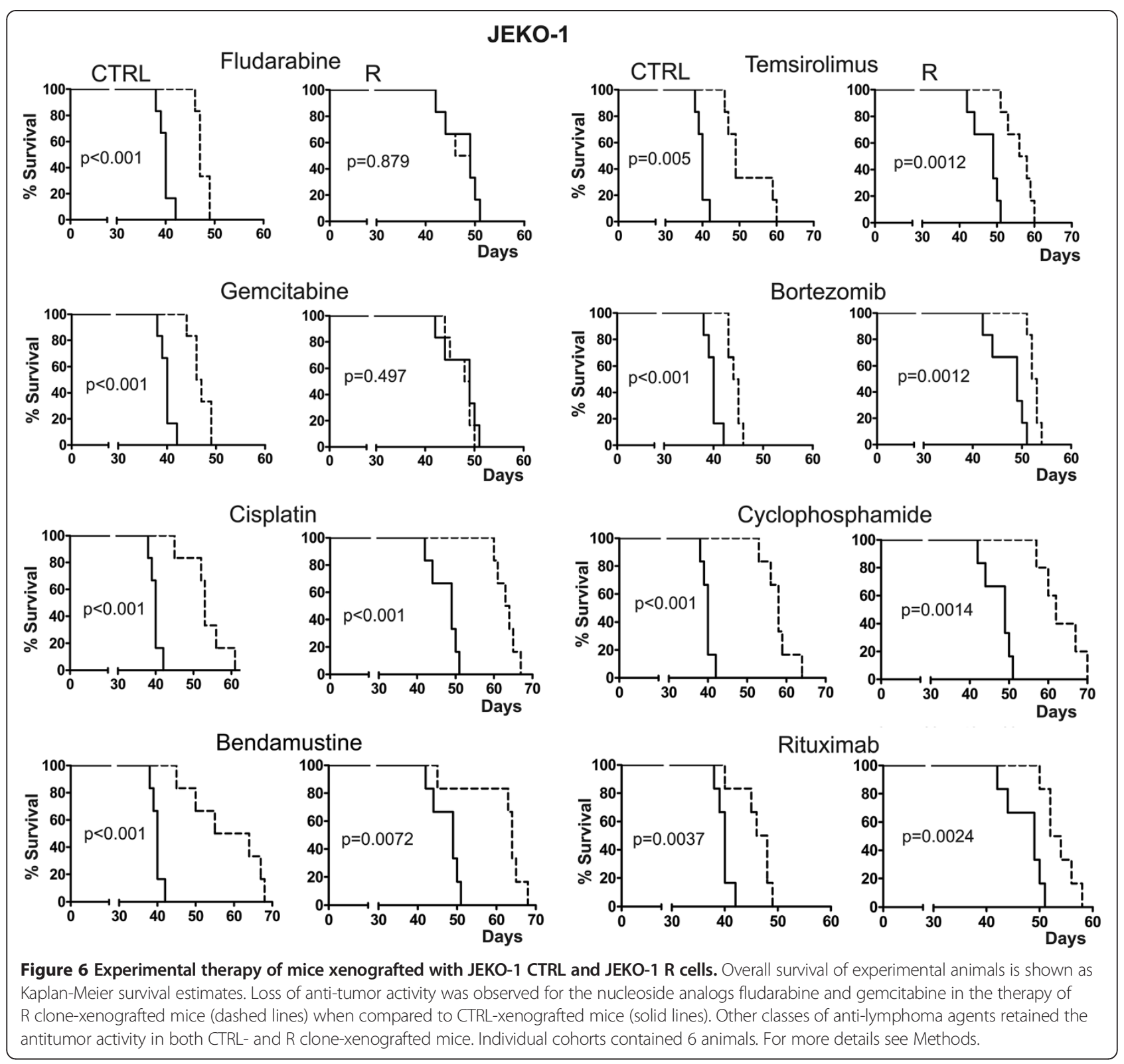

after high-dose araC-based regimen should not rely on nucleoside analogs, namely on the currently used agents fludarabine, gemcitabine and cladribine, since all of them must be phosphorylated by DCK to exert their antilymphoma activity. Instead, other classes of anti-lymphoma drugs should be applied in case of araC failure, i.e. in the setting of anticipated araC-resistance. Some of these agents have only recently been approved for the therapy of relapsed/refractory (RR-) MCL, temsirolimus in Europe, bortezomib and ibrutinib in USA. It might be speculated that high-dose therapy (given before autologous stem cell transplant) based on other agents than nucleoside analogs might prove more beneficial especially for those patients with suboptimal responses after induction araC-based immunochemotherapy (e.g. patients, who achieve partial remission, or patients with detectable minimal residual disease). In addition to the currently approved agents, bendamustine represents another extremely promising drug in MCL. Recently it was demonstrated that bendamustine potentiates the effect of araC by augmenting the level of intracellular ara-CTP, and the R-BAC (rituximab, bendamustine, araC) regimen was shown to be effective even in patients resistant to araC thus providing a treatment option even for the elderly and/or frail patients $[16,30,31]$. It might be speculated that the increased level of ara-CTP might partially offset the anticipated downregulation of DCK thereby explaining, why the combination of bendamustine and araC was shown to be effective even in patients, who relapsed after araCbased therapies [30]. 
Table 3 Gene expression analysis of DCK in a set of primary MCL samples obtained from patients before and after araC-based therapies

\begin{tabular}{|c|c|c|c|c|c|c|c|c|}
\hline $\begin{array}{l}\text { Sample at } \\
\text { diagnosis }\end{array}$ & Source & $\begin{array}{l}\Delta C T \text { (DCK- } \\
\text { GAPDH) }\end{array}$ & Therapy & $\begin{array}{l}\text { Sample at } \\
\text { relapse }\end{array}$ & $\begin{array}{c}\text { Disease-free survival } \\
\text { (months) }\end{array}$ & Source & $\begin{array}{l}\Delta \text { CT (DCK- } \\
\text { GAPDH) }\end{array}$ & $\begin{array}{c}\text { Difference in } \Delta C T \text { between } R \\
\text { and } D \text { samples }\end{array}$ \\
\hline D1 & PBMC & 3.4 & $A^{*}$ & R1 & 12 & PBMC & 3.7 & +0.3 \\
\hline D2 & $P E^{* * *}$ & 3.3 & A & R2 & 10 & $P E^{* * *}$ & 5.3 & +2.0 \\
\hline D3 & FFPE & 0.1 & A & R3 & 5 & FFPE & 1.3 & +1.2 \\
\hline D4 & FFPE & 1.7 & B & R4 & 4 & FFPE & 3.5 & +1.8 \\
\hline D5 & PBMC & 1.4 & A & R5 & 7 & PBMC & 2.2 & +0.8 \\
\hline D6 & PBMC & 4.1 & $B^{* *}$ & R6 & 3 & PBMC & 3.9 & -0.2 \\
\hline D7 & FFPE & 1.3 & B & R7 & 13 & FFPE & 3.5 & +2.2 \\
\hline D8 & FFPE & 2.0 & A & R8 & 25 & FFPE & 1.8 & -0.2 \\
\hline D9 & PBMC & 1.9 & B & R9 & N/A & PBMC & 3.3 & +1.4 \\
\hline D10 & PBMC & 2.3 & A & R10 & N/A & PBMC & 1.5 & -0.8 \\
\hline
\end{tabular}

${ }^{*} \mathrm{~A}=$ alternation of R-CHOP and R-araC (2 g/m2, 2 doses a $\left.24 \mathrm{~h}\right)$.

${ }^{*} \mathrm{~B}=$ Nordic protocol (alternation of R-MaxiCHOP and R-araC (2-3 g/m2, 4 doses a $12 \mathrm{~h}$ ).

***PE pleural effusion (CD19-sorted).

Samples from relapsed patients were obtained at diagnosis (D1-D8) and at lymphoma relapse after failure of araC-based therapies (R1-R8). Samples from refractory patients were obtained from primary araC-resistant MCL patients before (D9-D10) and 14 days after (R9-R10) administration of high-dose araC. Real-time RT-PCR was used to determine changes in DCK expression.

\section{Conclusions}

Our data from the cell lines and primary MCL samples clearly demonstrate that acquired resistance of MCL cells to $\mathrm{araC}$ is associated with downregulation of mRNA and protein expression of DCK, enzyme of the nucleotide salvage pathway responsible for phosphorylation of most nucleoside analogs used in anti-cancer therapy. In translation, the results suggest that 1 . nucleoside analogs should not be used for the second-line therapy of MCL patients, who fail after araC-based regimen; 2 . non-nucleoside analogs should be employed in this setting, including cisplatin, ibrutinib, temsirolimus, bortezomib or bendamustine; 3 . ibrutinib appears particularly effective in eliminating araC-resistant MCL cells.

\section{Methods}

\section{Cell culture}

JEKO-1, GRANTA-519 and REC-1 were purchased from German Collection of Microorganisms and Cell Cultures (DSMZ), MINO was from American Tissue Culture Collection (ATCC), HBL-2 was a kind gift of prof. Dreyling (University of Munich, Germany). Cell lines were cultured

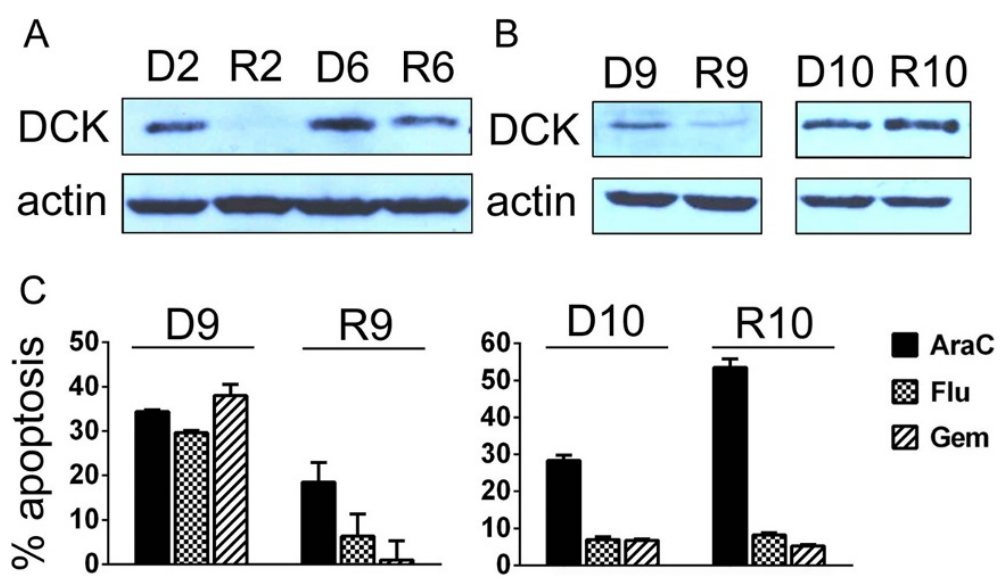

Figure 7 Protein expression of DCK in primary MCL samples, and their ex vivo sensitivity to nucleoside analogs. (A-B) Relative expression of deoxycytine kinase (DCK) in post-treatment primary MCL samples (R2, R6, R9, R10) compared to pre-treatment samples (D2, D6, D9, D10). (C) CD19-sorted PBMC cells were isolated from two leukemized araC-refractory MCL patients before (D9, D10) and 14 days after (R9, R10) administration of high-dose araC. The cells were ex vivo/in vitro exposed to araC $(25 \mu \mathrm{M})$, fludarabine $(F l u, 100 \mu \mathrm{M})$ and gemcitabine $(\mathrm{Gem}, 25 \mu \mathrm{M})$. Apoptosis was measured after 24 hours using standard Annexin-V-PE and flow cytometry. Apoptotic cells are shown as Annexin-V-PE-positive cells ( $Y$ axis). Basal apoptosis of drug-unexposed cells was subtracted from the apoptosis of the drug-exposed cells. 
in Iscove's modified Dulbecco's medium (IMDM) supplemented with $15 \%$ fetal bovine serum (FBS) and 1\% penicillin/ streptomycin.

\section{Reagents}

Cytarabine, fludarabine, gemcitabine, cladribine, cyclophosphamide, doxorubicin and cisplatin were from Clinical Dept. of Hematology, University Hospital in Prague, Czech Republic. Temsirolimus, bortezomib, bendamustine and ibrutinib were purchased from Selleck Chemicals. Rituximab was kindly provided by Roche, Czech Republic.

\section{Establishment of araC-resistant clones}

MCL cell lines were incubated in Iscove's modified Dulbecco's medium (IMDM) supplemented with 15\% fetal bovine serum with increasing concentrations of cytarabine up to $50 \mu \mathrm{M}$.

\section{Proliferation assays}

Proliferation was estimated using WST-8 Quick Cell Proliferation Assay Kit (BioVision) according to the manufacturer instructions. Briefly, 5.000 cells were seeded into 96-well plate on day 1 . Drugs were added on day 1. Proliferation was measured on day 1 and then since day 4 daily. Antiproliferative activity of each drug was analyzed at several concentrations.

Absorbance of the triplicate samples was measured on ELISA reader after 3 hour incubation with WST-8 reagent at 37 grades Celsius in the thermostat. Maximal absorbance $\left(\mathrm{MAX}_{\mathrm{u}}\right)$ obtained from the untreated cells during the particular experiment was arbitrary set as $100 \%$. Absorbance of medium without cells was used as background (B). For each cell population (both, unexposed and drug-exposed) and for each measurement $\left(\mathrm{M}_{1}, \mathrm{M}_{2}, \mathrm{M}_{3} \ldots \mathrm{M}_{\mathrm{X}}\right)$ the proliferation curve was calculated as follows: $\left(M_{X}-B\right) /\left(M_{A X}-B\right)$. As a consequence, the proliferation curve of untreated cells always peaks $100 \%$, while proliferation curves of drug-exposed cells can terminate below or above $100 \%$.

\section{${ }^{51} \mathrm{Cr}$ release assay for the assessment of the impact that CD20 mAbs have on rituximab-mediated complement mediated cytotoxicity (CMC) and antibody dependent cellular cytotoxicity (ADCC)}

CTRL MCL cells and R clones were labeled with ${ }^{51} \mathrm{Cr}$ at $37^{\circ} \mathrm{C}, 5 \% \mathrm{CO} 2$ for $2 \mathrm{hrs} .{ }^{51} \mathrm{Cr}$-labeled cells were then placed in 96-well plates at a cell concentration of $1 \times 10^{5}$ cells/well (complement-mediated cytotoxicity (CMC) assay) or $1 \times$ $10^{4}$ cells/well (antibody-dependent cell cytotoxicity (ADCC) assay). Cells were then exposed to rituximab $(10 \mathrm{mg} / \mathrm{ml})$ or isotype antibody $(10 \mathrm{mg} / \mathrm{ml})$ and human serum (for CMC assay, 1:4 dilution) or peripheral blood mononuclear cells (PBMCs) (for ADCC assay, 40:1 effector: target ratio) for six hrs at $37^{\circ} \mathrm{C}$ and $5 \% \mathrm{CO} 2 .{ }^{51} \mathrm{Cr}$ release was measured from the supernatant by standard gamma counting and the percentage of lysis was calculated. PBMCs were obtained from healthy donors (Roswell Park Cancer Institute IRBapproved protocol CIC-016) and isolated by Histopaque1077 ultracentrifugation of peripheral whole blood and used at an effector: target ratio of 40:1 for ADCC assays. Pooled human serum was used as the source of complement for $\mathrm{CMC}$ assays.

\section{Gene expression profiling and data analysis}

A biological duplicate of each araC-resistant MCL clone (R) was compared to a biological duplicate of the original araC-sensitive (CTRL) cell line. In total, five $\mathrm{R}$ clones were compared to five corresponding CTRL cell lines using two microarray chips. Total RNA was extracted by RNeasy Mini Kit (Qiagen), and its quality verified using the Agilent 2100 Bioanalyzer (Agilent Technology). Extracted RNA was amplified using the Illumina RNA Amplification Kit (Ambion). Amplified RNA was hybridized to the Illumina HumanRef- 8 and HumanRef-12 BeadChips (Illumina). Subsequent data analysis was performed in R-software, mainly in limma package from Bioconductor (http://www.bioconductor.org). Multiple testing correction was performed using Benjamini \& Hochberg method. The filtered group of genes with fold change at least \pm 1.5 fold and adjusted $\mathrm{p}$ value $<0.05$ were annotated and arranged into biologically relevant categories using The Database for Annotation, Visualization and Integrated Discovery (DAVID, http://david.abcc.ncifcrf.gov).

Primary MCL sample acquisition, real-time RT-PCR analysis, and apoptosis measurement

All primary MCL samples were obtained from patients with MCL at diagnosis (D1-D10), and at the relapse or during progression after failure of high-dose araC-based front-line therapies (R1-R10). Samples were obtained from patients, who signed informed consent according to the Declaration of Helsinki. Mononuclear cells were isolated from all PBMC and PE samples by the standard FicollHypaque gradient centrifugation. Mononuclear cells were then CD19 sorted on magnetic columns using CD19 microbeads (Miltenyi Biotec). The purity of MCL population after sorting was $>95 \%$ in all cases as verified by flowcytometry. Total RNA was isolated from CD19-sorted PBMC or PE cells stored in RNAlater solution using RNeasy Mini Kit (Qiagen, Hilden, Germany) and from fresh-frozen paraffin-embedded (FFPE) lymph node samples using High Pure RNA Paraffin Kit (Roche Diagnostics $\mathrm{GmbH}$, Germany) according to the manufacturer's instructions. cDNA synthesis was carried out from $1 \mu \mathrm{g}$ of total RNA with the High-Capacity cDNA Reverse Transcription Kit (random primers) (Applied Biosystems). Real-time RT-PCR was performed using TaqMan Gene Expression Assays on the ABI 7900HT detection system (Applied 
Biosystems). The reference gene was GAPDH. Ex vivo apoptosis of primary MCL cells was determined using Annexin-V-PE (Apronex, Czech Republic) and flow cytometry (BD FACS Canto II) according to the manufacturer's instructions after 24 hours exposure to $25 \mu \mathrm{M}$ araC, $100 \mu \mathrm{M}$ fludarabine and $25 \mu \mathrm{M}$ gemcitabine.

\section{Experimental therapy of $M C L$ xenografts}

In vivo studies were approved by the institutional Animal Care and Use Committee. Immunodeficient NOD.

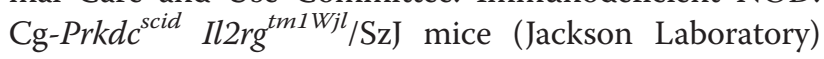
were maintained in individually ventilated cages. JEKO-1 cell line-based mouse model of MCL was used for experiments [32]. JEKO-1 cells were harvested, suspended in PBS, and injected $\left(1 \times 10^{6} /\right.$ mouse $)$ i.v. into tail vein of 8- to 12-week-old female mice on DAY 1 . Therapy was initiated on DAY 8. Each cohort of mice contained 6-8 animals. The mice received treatment as follows: temsirolimus $1 \mathrm{mg}$ s.c. $1 \mathrm{x}$ weekly ( 3 cycles), cyclophosphamide $3 \mathrm{mg}$ i.p. $1 \times$ weekly ( 3 cycles), bendamustine $0.5 \mathrm{mg}$ i.p. two subsequent days (day $1+$ day 2 ) every two weeks ( 2 cycles), bortezomib $25 \mu$ g i.p. $2 \times$ weekly ( 3 cycles), cisplatin $180 \mu \mathrm{g}$ i.p. every two weeks $(2$ cycles), gemcitabine $10 \mathrm{mg}$ i.p. $1 \times$ weekly ( 3 cycles), fludarabine $1 \mathrm{mg}$ three subsequent days (day $1-3)$ weekly ( 3 cycles), rituximab $250 \mu$ g s.c. $1 \times$ weekly ( 3 cycles). The data were analysed in GraphPad Software.

\section{Two-dimensional electrophoresis}

IPG strips (pH 4.0-7.0, $24 \mathrm{~cm}$; ReadyStrip, Bio-Rad) were rehydrated overnight in $450 \mu \mathrm{L}$ of sample, representing $1.5 \mathrm{mg}$ of protein. Isoelectric focusing was performed for $70 \mathrm{kVh}$ using Protean IEF cell (Bio-Rad). Six replicates were run for each cell type. Focused strips were equilibrated and reduced in equilibration (6 M urea, $50 \mathrm{mM}$ Tris $\mathrm{pH} 8.8,30 \%$ glycerol, $2 \%$ SDS) supplemented with DTT (450 mg per $50 \mathrm{~mL}$ ) for $15 \mathrm{~min}$ and then alkyled in equilibration buffer with added iodacetamide $(1.125 \mathrm{mg}$ iodacetamide per $50 \mathrm{~mL}$ ). SDS-PAGE electrophoresis was performed in a Tris-glycine-SDS system using a 12gel Protean Dodeca Cell apparatus (Bio-Rad) with buffer circulation and external cooling $\left(20^{\circ} \mathrm{C}\right)$. Gels were run at a constant voltage of $80 \mathrm{~V}$ per gel for $30 \mathrm{~min}$ and then at a constant voltage of $200 \mathrm{~V}$ for $6 \mathrm{~h}$. Gels were washed in deionized water to remove redundant SDS and with colloidal Coomassie Brilliant Blue (SimplyBlue ${ }^{\mathrm{Tm}}$ Safestain, Invitrogen, Carlsbad, CA, USA) overnight.

\section{Gel image analysis and extraction of peptides}

Stained gels were scanned with GS 800 calibrated densitometer (Bio-Rad) and image analysis was performed with Progenesis $^{\text {Tax }}$ software (Nonlinear Dynamics, Ltd., Newcastle upon Tyne, UK) in semi-manual mode with 6 gel replicates for each cell type. Normalization of gel images was based on total spot density, and integrated spot density values (spot volumes) were then calculated after background subtraction. Average spot volume values (averages from the all 6 gels in the group) for each spot were compared between the groups. Protein spots were considered differentially expressed if their average normalized spot volume difference was $>2$-fold. As determined by the Student's ttest, a p-value $<0.05$ was considered to indicate a statistically significant difference.

\section{Protein digestion and peptide extraction}

Spots containing differentially expressed proteins were excised from the gels, cut into small pieces and washed 3 times with $25 \mathrm{mM}$ ammonium bicarbonate in 50\% acetonitrile (ACN). The gels were then dried in a SpeedVac Concentrator (Eppendorf, Hamburg, Germany). Sequencing grade modified trypsin (Promega, Madison, WI, USA) ( $6 \mathrm{ng} / \mu \mathrm{l}$ in $25 \mathrm{mM}$ ammonium bicarbonate in $5 \%$ ACN) was added. Following overnight incubation at $37^{\circ} \mathrm{C}$, the resulting peptides were extracted with $50 \% \mathrm{ACN}$.

\section{MS analysis and protein identification}

Peptide samples were spotted on a steel target plate (Bruker Daltonics, Bremen, Germany) and allowed to dry at room temperature. Matrix solution (3 mg $\alpha$-cyano-4hydroxycinnamic acid in $1 \mathrm{ml}$ of $50 \%$ ACN containing $0.1 \%$ trifluoroacetic acid) was then added. MS was performed on an Autoflex II MALDI-TOF/TOF mass spectrometer (Bruker Daltonics, Bremen, Germany) using a solid nitrogen laser $(337 \mathrm{~nm})$ and FlexControl software in reflectron mode with positive ion mass spectra detection. The mass spectrometer was externally calibrated with Peptide Calibration Standard II (Bruker Daltonics). Spectra were acquired in the mass range $800-3,000 \mathrm{Da}$. The peak lists were generated using FlexAnalysis and searched against Swiss-Prot (2012_07 version, 536789 sequences) using Mascot software. The peptide mass tolerance was set to $100 \mathrm{ppm}$, taxonomy Homo sapiens, missed cleavage was set to 1 , fixed modification for cysteine carbamidomethylation, and variable modifications for methionine oxidation and protein $\mathrm{N}$-terminal acetylation. Proteins with Mascot score over the threshold 56 for $p<0.05$ calculated for the used settings were considered as identified. If the score was lower, the identity of protein candidate was confirmed by MS/MS.

\section{Western blot analysis}

Cells were lysed in NHT buffer $(140 \mathrm{mM} \mathrm{NaCl}, 10 \mathrm{mM}$ HEPES, 1.5\% Triton X-100, pH 7.4). Protein concentration in the collected supernatants was determined by the Bradford assay (Bio-Rad). Lysate samples $(50 \mu \mathrm{g})$ were combined with SDS loading buffer containing 2-mercaptoethanol and boiled for $5 \mathrm{~min}$. Quadruplicate samples were separated on 12\% SDS-PAGE minigels in Tris-glycine buffer (Bio-Rad). 
Electrophoresis was performed at a constant voltage for 30 min at $45 \mathrm{~V}$ per gel, and then at $90 \mathrm{~V}$ per gel until the dye front reached the gel bottom. Proteins were transferred onto $0.45 \mu \mathrm{m}$ PVDF membranes (Milipore, Billerica, MA, USA) in a semi-dry blotter (Hoefer, San Francisco, CA, USA) at $0.8 \mathrm{~mA} / \mathrm{cm}^{2}$. Membranes were incubated in PBS (Invitrogen) containing $0.1 \%$ Tween-20 and 5\% non-fat dried milk for $1 \mathrm{~h}$. GAPDH or Actin were used as the loading controls. As primary antibodies anti-deoxycytidine kinase mouse monoclonal antibody (sc 81245 Santa Cruz Biotechnology, Sanat Cruz, CA, USA) diluted 1:200 or polyclonal anti-GAPDH produced in rabbit (SigmaAldrich, G9545) diluted 1:10,000 were used. After thorough washing in blocking buffer, a secondary horseradish peroxidase-conjugated anti-mouse (sc2005) or anti-rabbit antibody (sc2313) (both from Santa Cruz Biotechnology) was added $(1: 10,000)$. The signal was detected using LumiGLO Reserve, (KPL, Gaithersburg, MD, USA) or Western Blotting Luminol Reagent (Santa Cruz Biotechnology, Inc., Santa Cruz, CA, USA) and membranes were exposed to X-ray films (Kodak, Rochester, NY, USA).

\section{Additional files}

Additional file 1: Figure S1. Functional cathegories of genes differentially expressed in R compared to CTRL as determined by DAVID. The filtered group of genes acquired from all five MCL cell lines with fold change at least \pm 1.5 -fold and adjusted $p$ value $<0.05$ were annotated and arranged into biologically relevant categories using The Database for Annotation, Visualization and Integrated Discovery (DAVID, http://david. abcc.ncifcrf.gov).

Additional file 2: Table S1. List of genes differentially expressed in more than one $\mathrm{R}$ clone compared to the corresponding CTRL cells. Microarray data are shown in Additional file 2: Table S1. 31 genes were differentially expressed in two araC-resistant clones (R) compared to the corresponding araC-sensitive controls (CTRL). 1 gene (TPM1) was differentially expressed in three $\mathrm{R}$ clones, and 1 gene (DCK) was differentially expressed in all five $\mathrm{R}$ clones compared to the corresponding CTRL.

Additional file 3: Figure S2. Ibrutinib appears more cytotoxic to cytarabine-resistant (R) compared to cytarabine-sensitive (CTRL) MCL cells. WST-8 cell proliferation assays of CTRL cells and R clones were carried out as described in Methods. Maximal absorbance obtained from the untreated cells during the particular experiment $\left(M_{A X}\right)$ was arbitrary set as $100 \%$. Absorbance of medium without cells was used as background (B). For each cell population (both, unexposed and drug-exposed) and for each measurement $\left(M_{1}, M_{2}, M_{3} \ldots M_{X}\right)$ the proliferation curve was calculated as follows: $\left(M_{X}-B\right) /\left(M A X_{u}-B\right)$. As a consequence, proliferation curves of untreated cells always peak at $100 \%$, while proliferation curves of drug-exposed cells can terminate below or above 100\%. One representative example of two independent experiments carried out on REC-1, HBL-2 and GRANTA-519 is shown. In summary, REC-1 R clone was $>100$-fold sensitive to Bruton tyrosine-kinase (BTK) inhibitor ibrutinib compared to REC-1 CTRL cells. Both HBL-2 and GRANTA-519 R clones were approx. 2-fold more sensitive to ibrutinib compared to HBL-2 and GRANTA-519 CTRL cells.

\section{Abbreviations}

ACN: Acetonitrile; ADCC: Antibody-dependent cytotoxicity; AML: Acute myelogeneous leukemia; BTK: Bruton tyrosine-kinase; araC: Cytarabine, a pyrimidine analog used for anticancer therapy; CDA: Cytidine-deaminase, a key inactivating enzyme of nucleotide salvage pathway; CMC: Complementmediated cototoxicity; CTRL: araC-sensitive MCL cell line; DCK: Deoxycytidinekinase, a rate-limiting enzyme of nucleotide salvage pathway;
DTT: Dithiothreitol; FFPE: Fresh-frozen paraffin-embedded (lymph node sections); HDAC: High-dose araC; i.v.: Intravenous injection; MCL: Mantle cell lymphoma; NHL: Non-Hodgkin lymphoma; NT5C2: Cytoplasmic 5'nucleotidase II, a key inactivating enzyme of nucleotide salvage pathway; PBMC: Peripheral-blood mononuclear cells; PE: Pleural effusion; R: araCresistant clone derived from araC-sensitive cell line; R-CHOP: A combination of rituximab, cyclophosphamide, doxorubicin, vincristin and prednisone; R-DHAP: A combination of rituximab, high-dose cytarabine, cisplatin and dexamethasone; RR-MCL: Relapsed/refractory mantle cell lymphoma; S.c.: subcutanous injection.

\section{Competing interests}

The authors declare that they have no competing interests.

\section{Authors' contributions}

PK and JP conceived of the study and participated in drafting of the manuscript. MK carried out gene expression analysis and in vivo experiments, $\mathrm{OV}$, LL and JP carried out proteomic analysis and western blotting. BM, DV, JM, $P V$ and LL participated in in vitro experiments. CM carried out chrome-releasing assays. VK performed the statistical analysis. FH and MV participated in the design of the study and helped to review the manuscript. RJ and MT carried out analysis of primary MCL samples. All authors read and approved the final manuscript.

\section{Authors' informations}

Jiri Petrak and Pavel Klener Jr are considered senior co-authors.

\section{Acknowledgements}

Financial Support: IGA-MZ NT13201-4/2012, GACR14-19590S, GA-UK 446211, GA-UK 253284 700712, GA-UK 595912, GA-UK 1270214, UNCE 204021, PRVOUK-27/ LF1/1, PRVOUK P24/LF1/3, SW-2013-266509 and BIOCEV - Biotechnology and Biomedicine Centre of the Academy of Sciences and Charles University in Vestec" (CZ.1.05/1.1.00/02.0109), from the European Regional Development Fund.

\section{Author details}

${ }^{1}$ Institute of Pathological Physiology, Charles University in Prague, First Faculty of Medicine, Prague, Czech Republic. ${ }^{2}$ First Department of Medicine Department of Hematology, General University Hospital and Charles University in Prague, Prague, Czech Republic. Institute of Pathology, General University Hospital and Charles University in Prague, Prague, Czech Republic. ${ }^{4}$ Departments of Immunology and Medicine, Roswell Park Cancer Institute, Buffalo, NY, USA. ${ }^{5}$ Institute of Hematology and Blood Transfusion, Prague, Czech Republic

Received: 29 January 2014 Accepted: 23 June 2014

Published: 27 June 2014

\section{References}

1. Dreyling M, Kluin-Nelemans HC, Beà S, Klapper W, Vogt N, Delfau-Larue M-H, Hutter G, Cheah C, Chiappella A, Cortelazzo S, Pott C, Hess G, Visco C, Vitolo U, Klener P, Aurer I, Unterhalt M, Ribrag V, Hoster E, Hermine O: Update on the molecular pathogenesis and clinical treatment of mantle cell lymphoma: report of the 11th annual conference of the European Mantle Cell Lymphoma Network. Leuk Lymphoma 2013, 54:699-707.

2. Jares $\mathrm{P}$, Colomer D, Campo E: Molecular pathogenesis of mantle cell lymphoma. J Clin Invest 2012, 122:3416-3423.

3. Delarue R, Haioun C, Ribrag V, Brice P, Delmer A, Tilly H, Salles G, Van Hoof A, Casasnovas O, Brousse N, Lefrere F, Hermine O: CHOP and DHAP plus rituximab followed by autologous stem cell transplantation in mantle cell lymphoma: a phase 2 study from the Groupe d'Etude des Lymphomes de I'Adulte. Blood 2013, 121:48-53.

4. Lefrère F, Delmer A, Suzan F, Levy V, Belanger C, Djabarri M, Arnulf B, Damaj G, Maillard N, Ribrag V, Janvier M, Sebban C, Casasnovas R-O, Bouabdallah R, Dreyfus F, Verkarre V, Delabesse E, Valensi F, Mclntyre E, Brousse N, Varet B, Hermine O: Sequential chemotherapy by $\mathrm{CHOP}$ and DHAP regimens followed by high-dose therapy with stem cell transplantation induces a high rate of complete response and improves event-free survival in mantle cell lymphoma: a prospective study. Leukemia 2002, 16:587-593.

5. Merli F, Luminari S, Ilariucci F, Petrini M, Visco C, Ambrosetti A, Stelitano C, Caracciolo F, Di Renzo N, Angrilli F, Carella AM, Capodanno I, Barbolini E, 
Galimberti S, Federico M: Rituximab plus HyperCVAD alternating with high dose cytarabine and methotrexate for the initial treatment of patients with mantle cell lymphoma, a multicentre trial from Gruppo Italiano Studio Linfomi. Br J Haematol 2012, 156:346-353.

6. Ferrero S, Dreyling M: The current therapeutic scenario for relapsed mantle cell lymphoma. Curr Opin Oncol 2013, 25:452-462.

7. Wang ML, Rule S, Martin P, Goy A, Auer R, Kahl BS, Jurczak W, Advani RH, Romaguera JE, Williams ME, Barrientos JC, Chmielowska E, Radford J, Stilgenbauer S, Dreyling M, Jedrzejczak WW, Johnson P, Spurgeon SE, Li L, Zhang L, Newberry K, Ou Z, Cheng N, Fang B, McGreivy J, Clow F, Buggy JJ, Chang BY, Beaupre DM, Kunkel LA, Blum KA: Targeting BTK with ibrutinib in relapsed or refractory mantle-cell lymphoma. N Engl J Med 2013, 369:507-516.

8. Goy A, Sinha R, Williams ME, Kalayoglu Besisik S, Drach J, Ramchandren R, Zhang L, Cicero S, Fu T, Witzig TE: Single-agent lenalidomide in patients with mantle-cell lymphoma who relapsed or progressed after or were refractory to Bortezomib: phase II MCL-001 (EMERGE) study. J Clin Oncol 2013, 31:3688-3695.

9. Goy A, Younes A, McLaughlin P, Pro B, Romaguera JE, Hagemeister F, Fayad L, Dang NH, Samaniego F, Wang M, Broglio K, Samuels B, Gilles F, Sarris AH, Hart S, Trehu E, Schenkein D, Cabanillas F, Rodriguez AM: Phase II study of proteasome inhibitor bortezomib in relapsed or refractory B-cell non-Hodgkin's lymphoma. J Clin Oncol 2005, 23:667-675.

10. Ansell SM, Tang H, Kurtin PJ, Koenig PA, Inwards DJ, Shah K, Ziesmer SC, Feldman AL, Rao R, Gupta M, Erlichman C, Witzig TE: Temsirolimus and rituximab in patients with relapsed or refractory mantle cell lymphoma: a phase 2 study. Lancet Oncol 2011, 12:361-368.

11. Witzig TE, Geyer SM, Ghobrial I, Inwards DJ, Fonseca R, Kurtin P, Ansell SM, Luyun R, Flynn PJ, Morton RF, Dakhil SR, Gross H, Kaufmann SH: Phase II trial of single-agent temsirolimus ( $\mathrm{CCl}-779)$ for relapsed mantle cell lymphoma. J Clin Oncol 2005, 23:5347-5356.

12. Vose JM: Mantle cell lymphoma: 2012 update on diagnosis, riskstratification, and clinical management. Am J Hematol 2012, 87:604-609.

13. Robak T, Lech-Maranda E, Janus A, Blonski J, Wierzbowska A, Gora-Tybor J: Cladribine combined with cyclophosphamide and mitoxantrone is an active salvage therapy in advanced non-Hodgkin's lymphoma. Leuk Lymphoma 2007, 48:1092-1101.

14. Morschhauser F, Depil S, Jourdan E, Wetterwald M, Bouabdallah R, Marit G, Solal-Céligny P, Sebban C, Coiffier B, Chouaki N, Bauters F, Dumontet C: Phase II study of gemcitabine-dexamethasone with or without cisplatin in relapsed or refractory mantle cell lymphoma. Ann Oncol 2007, 18:370-375.

15. Johnson SA: Use of fludarabine in the treatment of mantle cell lymphoma, Waldenström's macroglobulinemia and other uncommon B- and T-cell lymphoid malignancies. Hematol J 2004, 5(Suppl 1):S50-S61.

16. Visco C, Finotto S, Zambello R, Paolini R, Menin A, Zanotti R, Zaja F, Semenzato G, Pizzolo G, D'Amore ESG, Rodeghiero F: Combination of rituximab, bendamustine, and cytarabine for patients with mantle-cell non-Hodgkin lymphoma ineligible for intensive regimens or autologous transplantation. J Clin Oncol 2013, 31:1442-1449.

17. Ellison RR, Holland JF, Weil M, Jacquillat C, Boiron M, Bernard J, Sawitsky A, Rosner F, Gussoff B, Silver RT, Karanas A, Cuttner J, Spurr CL, Hayes DM, Blom J, Leone LA, Haurani F, Kyle R, Hutchison JL, Forcier RJ, Moon JH: Arabinosyl cytosine: a useful agent in the treatment of acute leukemia in adults. Blood 1968, 32:507-523.

18. Kantarjian H, Barlogie B, Plunkett W, Velasquez W, McLaughlin P, Riggs S, Cabanillas F: High-dose cytosine arabinoside in non-Hodgkin's lymphoma. J Clin Oncol 1983, 1:689-694.

19. Capizzi RL: Curative chemotherapy for acute myeloid leukemia: the development of high-dose ara-C from the laboratory to bedside. Invest New Drugs 1996, 14:249-256.

20. Lamba JK: Genetic factors influencing cytarabine therapy. Pharmacogenomics 2009, 10:1657-1674.

21. Clarke ML, Damaraju VL, Zhang J, Mowles D, Tackaberry $T$, Lang $T$, Smith KM, Young JD, Tomkinson B, Cass CE: The role of human nucleoside transporters in cellular uptake of $4^{\prime}$-thio-beta-D-arabinofuranosylcytosine and beta-D-arabinosylcytosine. Mol Pharmacol 2006, 70:303-310.

22. Capizzi RL, White JC, Powell BL, Perrino F: Effect of dose on the pharmacokinetic and pharmacodynamic effects of cytarabine. Semin Hematol 1991, 28(3 Suppl 4):54-69.

23. Cai J, Damaraju VL, Groulx N, Mowles D, Peng Y, Robins MJ, Cass CE, Gros P: Two distinct molecular mechanisms underlying cytarabine resistance in human leukemic cells. Cancer Res 2008, 68:2349-2357.
24. Hubeek I, Stam RW, Peters GJ, Broekhuizen R, Meijerink JPP, van Wering ER, Gibson BES, Creutzig U, Zwaan CM, Cloos J, Kuik DJ, Pieters R, Kaspers GJ: The human equilibrative nucleoside transporter 1 mediates in vitro cytarabine sensitivity in childhood acute myeloid leukaemia. $\mathrm{Br} J$ Cancer 2005, 93:1388-1394.

25. Tang J, Xie X, Zhang X, Qiao X, Jiang S, Shi W, Shao Y, Zhou X: Long term cultured $\mathrm{HL}-60$ cells are intrinsically resistant to Ara-C through high CDA activity. Front Biosci (Landmark Ed) 2012, 17:569-574.

26. DeAngelis LM, Kreis W, Chan K, Dantis E, Akerman S: Pharmacokinetics of ara-C and ara- $U$ in plasma and CSF after high-dose administration of cytosine arabinoside. Cancer Chemother Pharmacol 1992, 29:173-177.

27. Qin T, Jelinek J, Si J, Shu J, Issa JP: Mechanisms of resistance to 5-aza-2'deoxycytidine in human cancer cell lines. Blood 2009, 113(3):659-667.

28. Ewald B, Sampath D, Plunkett W: Nucleoside analogs: molecular mechanisms signaling cell death. Oncogene 2008, 27:6522-6537.

29. Galmarini CM, Mackey JR, Dumontet C: Nucleoside analogues: mechanisms of drug resistance and reversal strategies. Leukemia 2001, 15:875-890.

30. Visco C, Castegnaro S, Chieregato K, Bernardi M, Albiero E, Zanon C, Madeo $D$, Rodeghiero F: The cytotoxic effects of bendamustine in combination with cytarabine in mantle cell lymphoma cell lines. Blood Cells Mol Dis 2012, 48:68-75

31. Hiraoka N, Kikuchi J, Yamauchi T, Koyama D, Wada T, Uesawa M, Akutsu M, Mori S, Nakamura Y, Ueda T, Kano Y, Furukawa Y: Purine analog-like properties of bendamustine underlie rapid activation of DNA damage response and synergistic effects with pyrimidine analogues in lymphoid malignancies. PLoS One 2014, 9:1-14.

32. Klanova M, Soukup T, Jaksa R, Molinsky J, Lateckova L, Maswabi BC, Prukova D, Brezinova J, Michalova K, Vockova P, Hernandez-llizaliturri F, Kulvait V, Zivny J, Vokurka M, Necas E, Trneny M, Klener P: Mouse models of mantle cell lymphoma, complex changes in gene expression and phenotype of engrafted MCL cells: implications for preclinical research. Lab Invest in press.

doi:10.1186/1476-4598-13-159

Cite this article as: Klanova et al:: Downregulation of deoxycytidine kinase in cytarabine-resistant mantle cell lymphoma cells confers cross-resistance to nucleoside analogs gemcitabine, fludarabine and cladribine, but not to other classes of anti-lymphoma agents. Molecular Cancer 2014 13:159.

\section{Submit your next manuscript to BioMed Central and take full advantage of:}

- Convenient online submission

- Thorough peer review

- No space constraints or color figure charges

- Immediate publication on acceptance

- Inclusion in PubMed, CAS, Scopus and Google Scholar

- Research which is freely available for redistribution

Submit your manuscript at www.biomedcentral.com/submit
C) Biomed Central 